\title{
Development of value added Pasta with incorporation of malted finger millet flour
}

\author{
Jaya Tripathi ${ }^{1 *}$, Ranu Prasad $^{2}$, Alka Gupta $^{2}$ and Vinita Puranik ${ }^{1}$ \\ ${ }^{1}$ Centre of Food Technology, University of Allahabad, Allahabad (Uttar Pradesh), INDIA \\ ${ }^{2}$ Sam Higginbottom Institute of Agriculture, Technology \& Sciences, Allahabad (Uttar Pradesh), INDIA \\ *Corresponding author. E-mail: jayatripathi1009@gmail.com \\ Received: August 12, 2014; Revised received: June 20, 2015; Accepted: July 27, 2015
}

\begin{abstract}
This study considers the replacement of Semolina with malted finger millet flour containing wide range of nutrients in enrichment of pasta. The changes in nutritional constituents and bioactive compounds (TPC, Radical Scavenging Activity) of pasta were examined by adding malted finger millet flour to the pasta formulations at the level of $0\left(T_{0}\right), 10\left(T_{1}\right), 20\left(T_{2}\right), 30\left(T_{3}\right), 40\left(T_{4}\right)$ and $50\left(T_{5}\right)$ per cent flour replacement. The results indicated that $T_{4}$ sample of finger millet flour added pasta contained more protein content i.e. $12.65 \mathrm{~g}$ compared to that of control pasta $\left(\mathrm{T}_{0}\right)$ i.e. $7 \mathrm{~g}$. Same way the calorie content of value added pasta was higher i.e. $409.94 \mathrm{Kcal} / 100 \mathrm{~g}$ as compared to control pasta $\left(T_{0}\right)$ i.e. $324.40 \mathrm{Kcal} / 100 \mathrm{~g}$. Calcium content of value added pasta was comparatively very high i.e. $170.4 \mathrm{mg} / 100 \mathrm{~g}$ as compared to $15.3 \mathrm{mg} / 100 \mathrm{~g}$ of control. As far TPC content \& DPPH $\%$ were considered, $\mathrm{T}_{4}$ sample of pasta have higher amount of both i.e. $220 \mathrm{mg}$ Gallic acid eq. \& $53.38 \%$ as compared to control pasta ( $\left.\mathrm{T}_{0}\right)$ i.e. $220 \mathrm{mg}$ Gallic acid eq. \& $17.59 \%$ respectively. Pasta and related products are the most popular are the most popular food worldwide. Usually pasta and other extruded products are high in starch but low in dietary fiber, minerals and vitamins. The present study clearly indicates that the use of malted finger millet flour will improve nutritional quality of pasta in terms of antioxidant activity.
\end{abstract}

Keywords: Bioactive compounds, Finger millet, Malting, Pasta, Radical scavenging activity

\section{INTRODUCTION}

Nowadays demands for ready to eat foods like extruded products has been increased because of change in economic scenario, urbanization, increased women employment and increased per capita income. Pasta products are normally high in starch but low in dietary fiber, minerals, vitamins, phenolic compounds, etc. With an increasing concern by the health conscious population, more nutritious pasta products rich in minerals, phenolic compounds, and dietary fiber with low glycemic index, have become the subject of prior significance. Emphasizing on this, an effort was put forth to develop health pasta supplemented with malted finger millet (Eleusine coracana) flour which are rich vitamins, minerals, and antioxidants. Finger millet (Eleusine coracana) is an important staple food in the eastern and central Africa as well as some parts of India (Mazumdar et. al 2006). Finger millet is usually used for preparation of flour, pudding, porridge and roti (Chaturvedi and Srivastava, 2008). With the changes in scenario of utilization of processed products and awareness of the consumers about the health benefits, finger millet has gained importance because of its functional components, such as slowly digestible starch and resistant starch (Wadikar et al., 2007). The calcium content is higher than all cereals and iodine content is said to be highest among all the food grains. Ragi has best quality protein along with the presence of essential amino acids, vitamin A, vitamin B and phosphorus. Thus ragi is a good source of diet for growing children, expecting women's, old age people and patients (Desai et al., 2010). Traditionally finger millet is processed either by malting or fermentation (Rao and Muralikrishna, 2001). Malting of finger millet improves its digestibility, sensory and nutritional quality as well as pronounced effect in the lowering the antinutrients. Malting characteristics of finger millet are superior to other millets and ranks next to barley malt (Pawar and Dhanvijay, 2007). The malted and fermented finger millet flour are extensively used in preparation of weaning food, instant mixes, beverages and pharmaceutical products (Rao and Muralikrishna, 2001). Therefore, an attempt has been made through this study to utilise the malted finger millet to produce tasty and nutritious pasta, the demand of which has been increased among individuals.

\section{MATERIALS AND METHODS}

Test Materials: The present study was carried out in the Centre of Food Technology, University of Allahabad, Allahabad during January 2013- May 2013. Semolina and finger millet in a single lot were procured from the local market of Allahabad, India. To optimize the 
soaking period, germination period and germination temperature of finger millet, response surface methodology (RSM) was used while rest of the ingredients levels were kept constant on the basis of hit and trial method. The lower and upper limits for soaking period, germination temperature and germination period were taken as 8- 24 hours, $25-37^{\circ} \mathrm{c}$ and $24-72$ hours, respectively. The soaking period (16 hours), germination temperature $\left(31^{\circ} \mathrm{c}\right)$ and germination period (48 hours) was optimized for malting. The Optimized finger millet was then dried in hot air oven at $50^{\circ} \mathrm{c}$ for 24 hours. Vegetative parts were removed by rubbing and the millets were ground to power followed by storing in air-tight

Malted finger millet Flour + Semolina

Added vegetable fat and water required and prepared the Dough

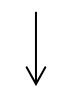

Passed the Dough through Pasta maker (Dolly Mini $\mathrm{P}_{3}$ Pasta Maker)

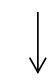

Cut into Pieces of 15-20 mm using a cutter<smiles>C=[V]</smiles>

Dried in Hot air oven at $55^{\circ} \mathrm{C}$ for 4 hours, Cooled and packed in Air tight containers

Fig. 1. Flow sheet for preparation of Pasta.

Table 1. Details of control and treatment combinations.

\begin{tabular}{lcccccc}
\hline \multirow{2}{*}{ Ingredients } & \multicolumn{6}{c}{ Treatments } \\
\cline { 2 - 7 } & $\mathbf{T}_{\mathbf{0}}$ & $\mathbf{T}_{\mathbf{1}}$ & $\mathbf{T}_{\mathbf{2}}$ & $\mathbf{T}_{\mathbf{3}}$ & $\mathbf{T}_{\mathbf{4}}$ & $\mathbf{T}_{\mathbf{5}}$ \\
\hline Semolina (\%) & 100 & 0 & 0 & 0 & 0 & 0 \\
Finger Millet (\%) & 0 & 10 & 20 & 30 & 40 & 50 \\
\hline
\end{tabular}

containers.

Chemical analysis: The proximate composition, calcium and iron content of malted finger millet flour and developed product was determined by AOAC (2007), whereas for estimation of total phenolic content, Folin-Ciocalteaue method was adopted Singleton et al. (1999). The radical scavenging activity was estimated by DPPH method given by De Ancos et al (2002).

Preparation of pasta: There were six combinations made for formulation of pasta as given in table 1 . The procedure of making pasta is given in figure 1 . Incorporation of malted finger millet flour to semolina was on replacement basis and incorporation level was $0,10,20,30,40,50$ percent, respectively.

\section{RESULTS AND DISCUSSION}

Proximate composition of malted finger millet flour and semolina: Malting of finger millet improves digestibility and bioavailability of nutrients, improves sensory and nutritional quality. From the table 2, it has been found that comparison of proximate composition of malted finger millet flour and semolina did not revealed any major difference. Rao (1994) also reported 8.2 and $11.3 \%$ protein content in brown and white varieties of malted finger millet, respectively. Kamath and Belavady (1980) found $18.6 \%$ dietary fibre and 3.6\% crude fibre in finger millet.

Calcium and iron content of malted finger millet flour: Calcium and iron content of malted finger millet flour were $386 \mathrm{mg}$ and $4.6 \mathrm{mg}$, respectively whereas the same of semolina were $14.5 \mathrm{mg}$ and $1.23 \mathrm{mg}$, respectively as shown in table 2. Mamiro et al. (2001) also reported that germination of finger millet for 48 hours has increased the in vitro extractability of calcium, iron and zinc.

Total phenolic content (TPC) and radical scavenging activity (DPPH) of malted finger millet flour: Table 3 shows that total phenolic content (TPC) and radical scavenging activity (DPPH) of malted finger millet flour was comparatively higher i.e., $124 \mathrm{mg} / 100 \mathrm{~g}$ Gallic acid eq. and 47.78 percent, respectively that that of

Table 2. Proximate and mineral composition of semolina, raw finger millet and malted finger millet (Mean \pm SD of three replicates).

\begin{tabular}{cccccccc}
\hline Particulars & $\begin{array}{c}\text { Moisture } \\
\mathbf{\%}\end{array}$ & $\begin{array}{c}\text { Crude Fat } \\
\text { \% }\end{array}$ & Protein \% & $\begin{array}{c}\text { Crude } \\
\text { Fiber \% }\end{array}$ & Ash \% & $\begin{array}{c}\text { Calcium } \\
\mathbf{m g} / \mathbf{1 0 0} \mathbf{g}\end{array}$ & $\begin{array}{c}\text { Iron } \\
\mathbf{m g} / \mathbf{1 0 0} \mathbf{g}\end{array}$ \\
\hline Semolina & $0.51 \pm 0.11$ & $0.83 \pm 0.15$ & $10.65 \pm 0.12$ & $0.4 \pm 0.15$ & $1.31 \pm 0.17$ & $14.5 \pm 0.11$ & $1.23 \pm 0.13$ \\
Raw Flour & $7.05 \pm 0.13$ & $1.1 \pm 0.12$ & $7.2 \pm 0.08$ & $3.3 \pm 0.26$ & $2.8 \pm 0.15$ & $337 \pm 0.20$ & $3.4 \pm 0.12$ \\
Malted Flour & $7.82 \pm 0.14$ & $2.48 \pm 0.17$ & $10.5 \pm 0.10$ & $3.16 \pm 0.20$ & $3.66 \pm 0.09$ & $386 \pm 0.13$ & $4.6 \pm 0.16$ \\
\hline
\end{tabular}

Table 3. Phyto-chemical composition of semolina, raw finger millet and malted finger millet (Mean $\pm \mathrm{SD}$ of three replicates).

\begin{tabular}{lll}
\hline Particulars & TPC $\mathbf{~ m g / 1 0 0 g}$ Gallic Acid Eq. & DPPH \% \\
\hline Semolina & $118 \pm 1.01$ & $37.30 \pm 0.98$ \\
Raw Finger Millet Flour & $335 \pm 0.92$ & $35.16 \pm 0.88$ \\
Malted Finger Millet flour & $124 \pm 0.98$ & $47.78 \pm 0.92$ \\
\hline
\end{tabular}


semolina i.e. $118 \mathrm{mg} / 100 \mathrm{~g}$ Gallic acid eq. and 37.30 percent, respectively.

Sensory evaluation: Table 4 shows that on the hedonic scale the scores for overall acceptability of pasta at 40 percent level of replacement was highest whereas all the treatments of pasta were also found to be acceptable by panel members. It is obvious from table that the pasta at level of 40 percent replacement was optimized and found best regarding the colour, texture, taste and overall acceptability. Suparat and Chomdao (2008) also studied the acceptability of pasta developed from brown rice and found the $30 \%$ replacement as acceptable.

Nutritional and phyto-chemical composition of malted finger millet incorporated pasta: Proximate composition of pasta incorporated with malted finger millet flour is given in table 5. Results showed that the crude fat percent and crude fibre percent and total ash value of optimized pasta increased slightly, whereas protein, energy value decreased. It might be due to replacement of semolina which is rich in protein and calories as compared to finger millet.

Mineral and phyto-chemical content of malted finger millet incorporated pasta: The calcium and iron content of pasta with and without incorporation of malted finger millet flour is given in table 6 . Results revealed that calcium and iron content increased after incorporating malted finger millet flour. Calcium content of malted finger millet incorporated pasta was very high i.e., $170.4 \mathrm{mg} / 100 \mathrm{~g}$ as compared to as compared to control pasta i.e., $15.3 \mathrm{mg} / 100 \mathrm{~g}$. So this malted finger millet flour incorporated pasta can also be recommended to post menopausal stage individuals who face calcium deficiency and bone related problems as the product is highly rich in calcium. Kulkarni et al. (2012) also reported that noodles supplemented with malted ragi lour was rich in protein, crude fibres and minerals especially calcium, iron and phosphorus as compared to the control sample.The present study indicated that total phenolic content (TPC) and radical scavenging activity (DPPH) of malted finger millet flour incorporated pasta was comparatively higher i.e. $220 \mathrm{mg} / 100 \mathrm{~g}$ gallic acid eq. and $53.38 \%$ respectively that that of control pasta i.e. $130 \mathrm{mg} / 100 \mathrm{~g}$ gallic acid eq. and $17.59 \%$, respectively.

\section{Conclusion}

It was concluded that incorporation of malted finger millet flour to pasta development improved the antioxidant and neutraceuticals properties of pasta by increasing its content of minerals (calcium and iron). Therefore, malted cereals hold a good potential as a source of neutraceuticals in food formulations. The products made from different malted millet flours are nutritionally superior to controls and can be successfully used for supplementary feeding programmers. Efforts should be made to educate people about nutritive value and health benefits of finger millet and its food products.

\section{REFERENCES}

AOAC. (2007). Official methods of analysis 18th edition. Association of official Analytical Chemists, Washington, DC.Anuradha D. Desai, Sharduli S. Kulkarni, A.K. Sahoo, R.C. Ranveer and P.B. Dandge. (2010). Effect of Supplementation of Malted Ragi Flour on the Nutritional and Sensorial Quality Characteristics of Cake. Adv. J. Food Sci. and Tech., 2:67-71.

Chaturvedi, R. and S. Srivastava. (2008). Genotype variations in physical, nutritional and sensory quality of popped grains of amber and dark genotypes o finger millet. $J$. Food Sci. Technol., 45(5): 443-446.

De Ancos, B., Sgroppo, S., Plaza, L., and Cano, M. P. (2008).Possible nutritional and health-related value promotion in orange juice preserved by high-pressure treatment. J. Sci. Food and Agri. 82:790-796.

Table 4. Effect of malted finger millet flour quantities on sensory attributes of pasta (Mean $\pm \mathrm{SD}$ of three replicates).

\begin{tabular}{ccccc}
\hline Treatments & Colour & Texture & Taste & Overall Acceptability \\
\hline $\mathrm{T}_{0}$ & $7.13 \pm 0.05$ & $7.05 \pm 0.06$ & $7.60 \pm 0.07$ & $7.18 \pm 0.18$ \\
$\mathrm{~T}_{1}$ & $6.26 \pm 0.09$ & $6.73 \pm 0.04$ & $6.40 \pm 0.06$ & $6.83 \pm 0.11$ \\
$\mathrm{~T}_{2}$ & $6.81 \pm 0.13$ & $6.63 \pm 0.09$ & $6.81 \pm 0.09$ & $6.53 \pm 0.23$ \\
$\mathrm{~T}_{3}$ & $7.18 \pm 0.20$ & $7.11 \pm 0.13$ & $7.20 \pm 0.15$ & $6.93 \pm 0.09$ \\
$\mathrm{~T}_{4}$ & $7.0 \pm 0.04$ & $8.03 \pm 0.19$ & $7.54 \pm 0.07$ & $7.23 \pm 0.15$ \\
$\mathrm{~T}_{5}$ & $7.2 \pm 0.23$ & $7.18 \pm 0.04$ & $7.12 \pm 0.03$ & $6.76 \pm 0.12$ \\
\hline
\end{tabular}

Table 5. Proximate composition of control and optimized pasta (Mean \pm SD of three replicates).

\begin{tabular}{cccccc}
\hline Particulars & Moisture \% & Crude Fat \% & Protein \% & Crude fiber \% & Ash \% \\
\hline Control Pasta & $5.89 \pm 0.19$ & $7.63 \pm 014$ & $13.78 \pm 0.12$ & $1.45 \pm 0.15$ & $1.56 \pm 0.15$ \\
Optimized Pasta & $5.69 \pm 0.17$ & $12.65 \pm 0.15$ & $8.48 \pm 0.11$ & $1.50 \pm 0.13$ & $1.76 \pm 0.14$ \\
\hline
\end{tabular}

Table 6. Mineral and phyto-chemical composition of control and optimized pasta (Mean \pm SD of three replicates).

\begin{tabular}{ccccc}
\hline Particulars & Calcium $\mathbf{~ m g / 1 0 0 ~ g}$ & Iron $\mathbf{~ m g / 1 0 0 ~ g}$ & TPC $\mathbf{~ m g / 1 0 0 ~ g ~ G a l l i c ~ a c i d ~ e q . ~}$ & DPPH \% \\
\hline Control Pasta & $15.3 \pm 0.56$ & $1.29 \pm 0.09$ & $130 \pm 1.08$ & $17.59 \pm 0.97$ \\
Optimized Pasta & $170.4 \pm 0.59$ & $2.46 \pm 0.11$ & $220 \pm 1.04$ & $53.38 \pm 0.93$ \\
\hline
\end{tabular}


Desai A.D., Kulkarni S.S., Sahoo A.K., Ranveer R.C. and Dangde P.B. (2010). Effect of Supplementation of Malted Ragi Flour on the Nutritional and Sensorial Quality Characteristics of Cake. Adv. J. Food Sci. Technol., 2(1): 67-71

Kamath M.V., Belavady B. (1980). Unavailable carbohydrates of commonly consumed Indian foods. J. Sci. Food Agri., 31: 194-202.

Kulkarni S.S., Desai A.D., Ranveer R.C. and Sahoo A.K. (2012). Development of nutrient rich noodles by supplementation with malted ragi flour. Int. Food Research Journal, 19(1): 309-313.

Mamiro R.S., John Van Camp UGent, Mwikya S.M. and André Huyghebaert (2001). In vitro extractability of calcium, iron and zinc in finger millet and kidney beans during processing. J. Food Sci., 66 (9): 1271-1275.

Majumder, T.K., K.S. Premavalli and A.S. Bawa, (2006). Effect of puffing on calcium and iron contents of ragi varieties and their utilization. J. Food Sci. Technol., 42 (5): $542-545$.
Pawar, P.A. and V.P. Dhanvijay. (2007). Weaning foods: An overview. Beverage Food World. 34(11): 27-33. Rao, P.U. (1994). Evaluation of protein quality of brown and white ragi (Eleusine coracana) before and after malting. Food Chem., 51: 433-436.

Rao S.M.V.S.S.T. and G. Muralikrishna, (2001). Non starch polysaccharides and bound phenolic acids from native and malted finger millet (Ragi, Eleusine coracana, Indaf-15). Food Chem., 72 : 187-192.

Suparat Reungmaneepaitoon and Chomdao Sikkhamondhol (2008). Development of Pasta Products from High-Iron Rice and Iron-Fortified Rice Flour. Kasetsart Journal -Natural Science, 42: 367 - 37

Singleton, V.L., Orthofer, R., Lamuela-Raventos, R.M. (1999). Analysis of total phenols and other oxidation substrates and antioxidants by means of Folin-Ciocalteu reagent. Methods Enzymol., 299:152-178.

Wadikar, D.D., R.S. Premvalli, Y.S. Satyanarayanswamy and A.S. Bawa.(2007). Lipid profile in finger millet. $J$. Food Sci. Technol., 44(1): 79-81. 